\title{
T Cell Receptor (TCR) Gene Rearrangement During the Course of Chronic Hepatitis B. A Preliminary Report.
}

Purnomo Soeharso

\begin{abstract}
Abstrak
Limfosit T mengenal antigen melalui reseptor di permukaan sel (TCR) setelah berinteraksi dengan molekul MHC sendiri ("self $M H C ")$. Untuk mengenal antigen yang sangat besar jumlahnya, TCR mempunyai struktur molekul yang sangat bervariasi, dihasilkan dari rearrangement gen TCR pada maturasi limfosit seperti yang terjadi pada gen imunoglobulin. Meskipun telah diketahui bahwa sel T berperan pada proses serokonversi penderita hepatitis B khronik atau karier, akan tetapi mekanismenya belum jelas. Untuk mengetahui rearrangement gen TCR pada penderita hepatitis B khronik, dilakukan transfer DNA yang diisolasi dari lekosit darah perifer (PBMC) menurut cara Southern, dan dihibridisasi dengan pelacak gen TCR yang spesifik. Rearrangement dapat dideteksi pada sekurangkurangnya 5\% dari populasi PBMC. Rearrangement lebih sering ditemukan pada penderita dengan antigen e positip dan lebih jarang pada penderita yang antigen e negatip. Patron rearrangement $5 \mathrm{~kb}$ EcoRI dan $5,5 \mathrm{~kb}$ Hind III merupakan penanda yang sering dijumpai pada karier hepatitis $B$ dengan antigen e positip. Pemeriksaan berkala pada 6 penderita hepatitis $B$ khronik memperlihatkan adanya penanda rearrangement sebelum serokonversi dan dapat terus terdeteksi selama 6 bulan sesudah serokonversi. Dengan demikian dapat diduga bahwa munculnya klon sel T dengan patron rearrangement tertentu menjadi penanda terjadinya serokonversi. Identifikasi klon tersebut akan diteliti lebih lanjut.
\end{abstract}

\begin{abstract}
$T$ cells recognize specific antigens through the T cell receptor (TCR) and self MHC molecules. Structural variation in the TCR to recognise the enormous diversity of antigens is effected by maturation rearrangement of TCR genes in a manner analogous to immunoglobulin genes. Although it is believed that $T$ cells play a major role in the seroconversion of e Ag positive hepatitis $B$ carriers, the mechanisms are still unclear. To examine the role of TCR rearrangements in chronic hepatitis $B$ we have carried out Southern transfers of DNA aliquots from peripheral blood mononuclear cells (PBMC) using TCR chain specific probes. Rearrangements affecting as few as $5 \%$ of PBMC could be detected. Rearrangements were more common in e Ag positive than negative. Of several rearrangement patterns a $5 \mathrm{~kb}$ EcoRl and $5.5 \mathrm{~kb}$ Hind III were most common. Longitudinal studies of 6 patients suggested the appearence of the rearrangement band preceded seroconversion and could be detected in PBMC for 6 months after seroconversion. It is postulated that during seroconversion the appearance of a clone of $T$ cells with a particular rearrangement is associated with seroconversion and characterisation of these clones is currently being undertaken.
\end{abstract}

Keywords : T cell receptor, Gene rearrrangement, Chronic hepatitis B

\section{INTRODUCTION}

The disease course of chronic hepatitis B is variable, with patients fluctuating between remission and active disease, as monitored by markers of liver destruction and virus replication. It is important to understand $T$ cell activity during the course of chronic hepatitis B, as it may provide a means of monitoring the disease, and possibly will be of benefit for immunological intervention in care or treatment strategies.

From several studies, it appeared that different phases of disease progression can be recognized over the years during the long course of chronic hepatitis $\mathrm{B} .{ }^{1,2,3}$ These phases reflect variations in host 
immune response to $\mathrm{HBV}$ during different occasions of chronic infection.

Application of TCR gene rearrangement analysis during the course of chronic HBV infection would be useful in defining the disease progress, as it may reflect the immunological state in different phases of chronic disease. The observation of TCR gene rearrangement bands may thus be linked to the features most predictive of outcome in chronic hepatitis B. As discussed in several publications, these are serum aminotransferase level indicating liver destruction, and serologic markers of virus replication indicated by $\mathrm{HBeAg}$ present in the serum. ${ }^{4}$

The possibility that there are changes of $\mathrm{T}$ cell clonality during the course of chronic HBV infection and the use of serum aminotransferase level and a virus replication marker as the indicators of disease chronicity, prompted the application of TCR gene rearrangement analysis in association with serum transaminase level and the presence of $\mathrm{HBeAg}$ in the serum of patients from whom blood had been taken on several occasions. This examination may provide a means for the evaluation of host immunity in virus-induced chronic hepatitis $\mathrm{B}$, that may be advantageous for the strategy of chronic hepatitis B treatment.

\section{SUBJECTS AND METHODS}

\section{Subjects}

Subjects were 6 patients with chronic hepatitis B who had been tested serologically for HBeAg and anti-HBe as virus replication markers; the test was performed using commercial ELISA kit (Abbott laboratories, IL). Subjects were also tested for serum alanine transferase (ALT) level as a marker for liver destruction, using a standard method. The tests were carried out by the Pathology Department, Royal Brisbane Hospital, over a period ranging from 15 to 37 months. The blood was taken at least once in 2 or 3 months.

\section{Methods}

Genomic DNA was isolated from $10 \mathrm{ml}$ of heparinized blood. $10 \mathrm{ug}$ of genomic DNA was then digested completely with EcoR 1 or Hind III in an appropriate buffer concentration overnight. DNA fragments were size fractionated by electrophoresis in $0.8 \%$ agarose and the separated DNA fragments were transfered to Hybond Nylon membrane (Amersham). The filter containing DNA fragments was then hybridized with the ${ }^{32} \mathrm{P}$-labelled TCR $B$ CDNA probe overnight. At the end of the hybridization the filter was washed several timeswith $2 \times$ down to $0.1 \times$ SSC containing $0.1 \%$ SDS, and finally the filter was autoradiographed.

\section{RESULTS}

To determine whether the detection of TCR $\beta$ gene rearrangements might be correlated with the pathogenesis of chronic hepatitis B, the appearance of rearrangement bands during the disease course of these six patients was associated with the disease progress which was assessed by regular testing of ALT level and serum $\mathrm{HBe} A g$. The pattern of TCR $B$ gene rearrangement, ALT level and serum HBeAg were plotted in one chart, and the results are shown in Figure 1.

As shown in case 1 (MY), the presence of rearrangement bands of $5.0 \mathrm{~kb}$ EcoR 1 and / or $5.5 \mathrm{~kb}$ Hind III DNA fragments coincided with high ALT level and the presence of $\mathrm{HBeAg}$ in the serum, detected in the period of $5 / 88$ to $2 / 89$. As the patient underwent seroconversion and the ALT dropped to moderate level, the rearrangement bands become undetectable as shown in $9 / 89$. Nine months later $(6 / 90)$ the serum was again $\mathrm{HBeAg}$ positive, and the ALT level increased to a higher level, although not as high as in the period before seroconversion; rearrangement bands appeared again, but the size was different from those before seroconversion.

In case $2(\mathrm{MF})$, the $5.0 \mathrm{~kb}$ EcoR 1 and $5.5 \mathrm{~kb}$ Hind III rearrangement bands were also detectable and coincided with high ALT level and HBeAg positive serum as indicated in the period of $8 / 88$ to $1 / 89$. At the time of seroconversion between $6 / 89$ and $11 / 89$, the ALT dropped to normal level. At this time the presence of rearrangement bands was not assessed. Four months later $(3 / 90)$ the ALT increased to a high level and reached a maximum in 5/90; the serum become $\mathrm{HBeAg}$ positive again, the $5.0 \mathrm{~kb}$ EcoR 1 and $5.5 \mathrm{~kb}$ Hind III rearrangement bands also reappeared. The $5,0 \mathrm{~kb}$ EcoR1 band was undetectable in the begining of ALT elevation in $3 / 90$, probably because the amount of the $T$ cell clone of interest at that time was less than the threshold of detection sensitivity. Four months later (9/90) the patient underwent seroconversion and the ALT dropped to normal level; this stage persisted until 9/91, during which rearrangement bands of TCR $B$ gene were undetectable.

In case 3 (BW), there were no detectable EcoR 1 rearrangement bands during 23 months of chronic disease course. the appearance of the $5.5 \mathrm{~kb}$ Hind III rearrangement band coincided with serum being HBeAg positive and with a high ALT level as in 3/89 and $9 / 89$. As patient underwent seroconversion and ALT dropped to normal level in $1 / 90$ the Hind III 
rearrangement band became undetectable, and remained so through $2 / 91$.

In case 4 (DD), the patient had not cleared the virus completely following 20 months of disease course. The $5.0 \mathrm{~kb}$ EcoR1 and $5.5 \mathrm{~kb}$ Hind III rearrangement bands were detectable, coinciding with serum being $\mathrm{HBeAg}$ positive and with high ALT level as seen in the period between $10 / 88$ and $3 / 88$. These rearrangement bands disappeared as the ALT dropped to normal level in $8 / 89$, when $\mathrm{HBeAg}$ was still present in trace amount in the serum (borderline). This stage persisted until 6/90.

In case 5 (DHD), the $\mathrm{HBeAg}$ was always negative during the course of chronic disease. ALT level increased slightly in the first 5 month period and reached a maximum in 6/89, during which $5.0 \mathrm{~kb}$ EcoR1 and $5.5 \mathrm{~kb}$ Hind III rearrangement bands were detectable. When ALT dropped to normal level in $8 / 89$ the rearrangement bands were undetectable. This situation proceed until 3/90, when ALT level increased to moderate level and the $5.0 \mathrm{~kb}$ EcoR 1 and $5.5 \mathrm{~kb}$ Hind III rearrangement bands reappeared. Six months later, the rearrangement bands disappeared again, coincident with the decreased ALT level.

Case $6(\mathrm{KC})$ is unique in that the rearrangement of TCR $\beta$ gene in peripheral blood T cells was detectable simultaneously with the rising ALT level and become undetectable as ALT dropped to normal level. However, the $\mathrm{HBeAg}$ was always negative during the course of the disease.

The results of monitoring TCR $\beta$ gene rearrangement during the disease course on these 6 patients is summarized in table 1 and the general feature of the relationship of TCR $\beta$ gene rearrangement, ALT level and serum $\mathrm{HBeAg}$ can be illustrated in Figure 2.

\section{DISCUSSION}

The appearance of TCR gene rearrangement bands in peripheral blood DNA, is associated with clonal expansion of a $\mathrm{T}$ cell clone to a proportion of at least $5 \%$ of total mononuclear cells, as has been confirmed previously. ${ }^{5}$ Clonal expansion of $\mathrm{T}$ cells would occur if there were a specific stimulation that induced specific $\mathrm{T}$ cells to become sensitized and undergo proliferation. Some previous experiments have reported that peripheral blood lymphocytes of chronic $\mathrm{HBeAg}$ positive patients are sensitized to $\mathrm{HBcAg} .{ }^{67}$ Furthermore, some experiments suggest that the peripheral blood mononuclear cell commpartments in patients with chronic active hepatitis B (CAH.B) contain cytotoxic $\mathrm{T}$ cells specific for $\mathrm{HBcAg} .{ }^{8,9} \mathrm{HBcAg}$ induces important immune reactions to cytotoxic class
I restricted $\mathrm{T}$ lymphocytes responsible for the elimination of HBV-infected hepatocytes. ${ }^{7,10}$ In addition to cellular cytotoxicity, lymphokine secretion is another important consequence of T cell activation, which contribute to the outcome of viral disease. ${ }^{11}$ One of the important lymphokines is gamma-interferon, which has been well known for its antiviral effect, but may also contribute to cytotoxic events by upregulating the expression of HLA molecules on the susceptible target cells. ${ }^{12}$ This finding is likely to be relevant to the result of this study. The $5.0 \mathrm{~kb}$ EcoR 1 and $5.5 \mathrm{~kb}$ Hind III rearrangement bands may correlate with clonal expansion of cytotoxic $\mathrm{T}$ cells specific to $\mathrm{HBcAg}$ or regulatory $\mathrm{T}$ cells that mediate immune response by releasing lymphokines.

This study examined the hypothesis that TCR $B$ gene rearrangement in peripheral blood $\mathrm{T}$ cells is a manifestation of immune progression in chronic hepatitis B. The experimental approach was based on the consideration that clonal proliferation of $T$ cells in peripheral blood correlate with cell mediated immunity to virus infection, and linked to the activity of $\mathrm{T}$ cells in the site of inflammation in the liver.

It was found in this study that only few rearrangement bands of TCR $B$ genes were observed in peripheral blood of chronic hepatitis $B$, indicating few clones of $\mathrm{T}$ cells to proliferate and detectable by direct examination of TCR $\beta$ gene rearrangement of white blood cells. Dominant clones carrying TCR gene detectable as $5.0 \mathrm{~kb}$ EcoR1 and 5.5 Hind III DNA fragments appear in most patients examined. This rearrangement bands change dynamically during the disease course concurrent with immune attack to infected liver in the process of viral clearance. A previous study by Moebius et $\mathrm{al}^{13}$ found that liver infiltrating lymphocytes distribute polyclonally as detected by TCR B gene rearrangement analysis on $\mathrm{T}$ cell clones from liver of chronic active hepatitis $\mathrm{B}(\mathrm{CAH})$ patients. It is likely that sensitized $\mathrm{T}$ cell clones expand in peripheral blood are part of those present in the site of inflamation in the liver. There are only small proportion of sensitized $\mathrm{T}$ cells in peripheral blood as most of them are sequestered into the liver for clearance of virus infected cells, and only cells with considerable expansion would be detectable by the present method. ${ }^{5}$

The activity of $T$ cells, as indicated by TCR $?$ gene rearrangement detectable in peripheral blood was examined for association with liver destruction and virus clearance during disease progression.

As shown in figure 1, presenting 6 cases, the TCR $B$ gene rearrangement bands of $5.0 \mathrm{~kb}$ EcoR1 and/or $5.5 \mathrm{~kb}$ Hind III DNA fragments were usually detectable several months before seroconversion, coinci- 
Figure 1. Time course of the appearance of markers virus replication (HBeAg) and seroconversion (anti-HBe) in the serum, liver damage (indicated by seru ALT level) and TCR B gene rearrangements detectable when peripheral blood mononuclear cell DNA was digested with ECORI or Hind III, in 6 patients with chronic hepatitis B. The presence of HBeAg or anti-HBe in the serum is indicated by positive $(+)$ or negative (-) signs. Changes of ALT level are indicated by graph lines. Dates on the abscissa indicate date of blood collections. Detectable rearrangement bands are indicated by a positive (+) sign along with the size of rearrangement band (in brackets). A negative (-) sign indicates that rearrangement band bands were not detectable (case 1, 2, 3, 4, 5 and 6 ).

CASE 1. Name : MY, Sex : Male, Age : 37 years

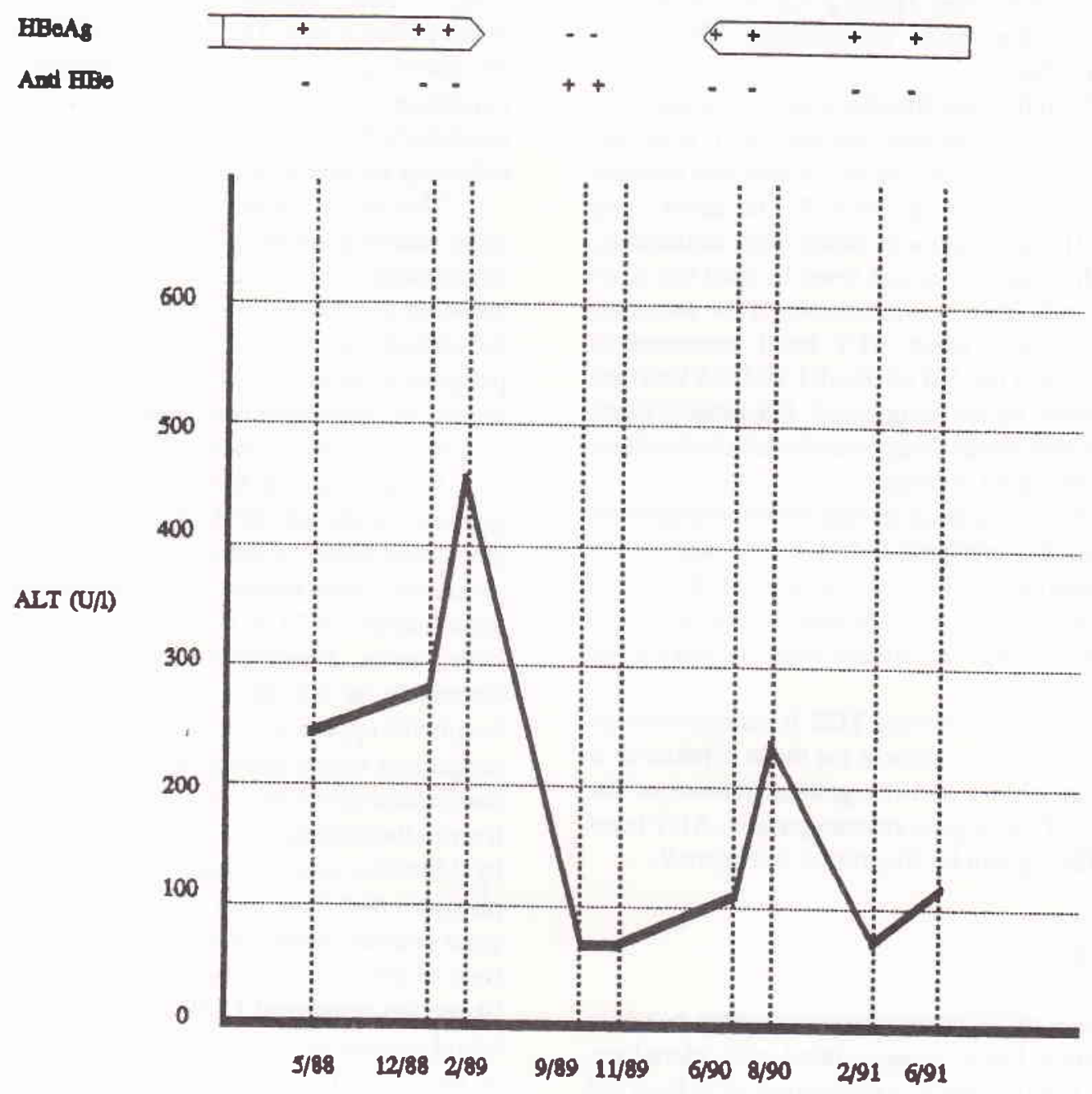

BcaR1

$+(5)+(5)$

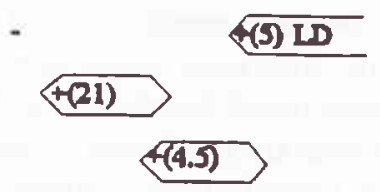

Find III

$+(5.5)+(5.5)$


CASE 2. Name : MF, Sex : Male, Age : 45 years

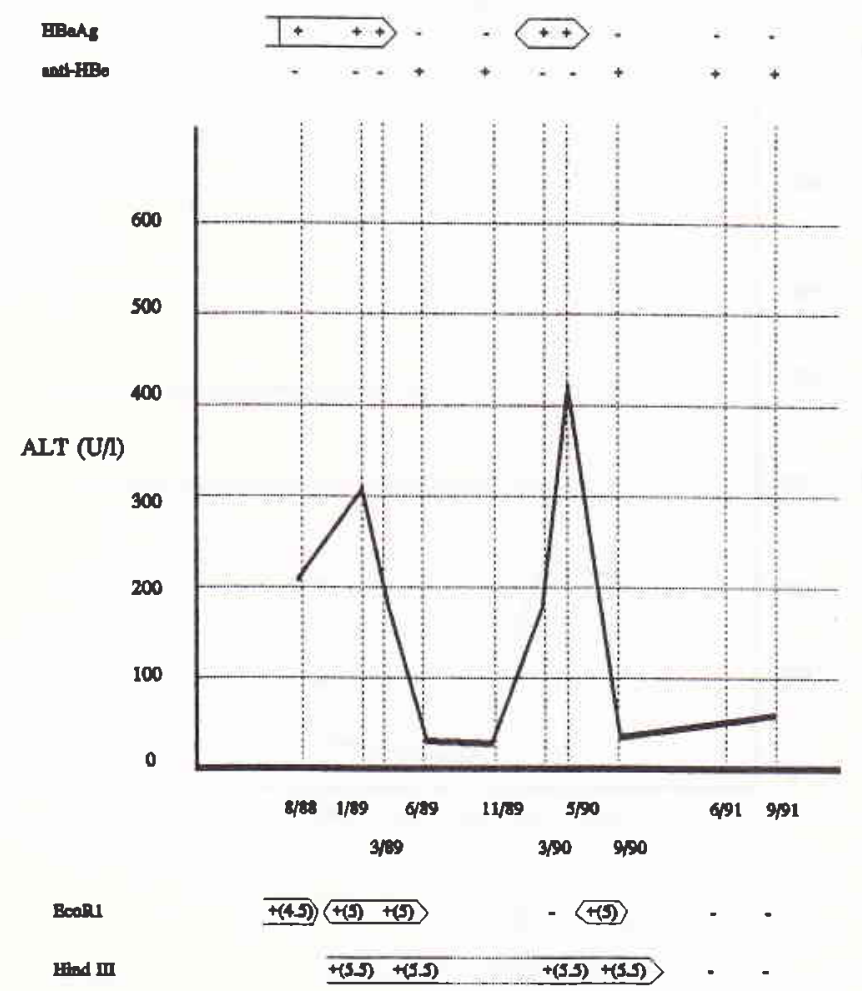

CASE 3. Name : BW, Sex : Male, Age : 50 years

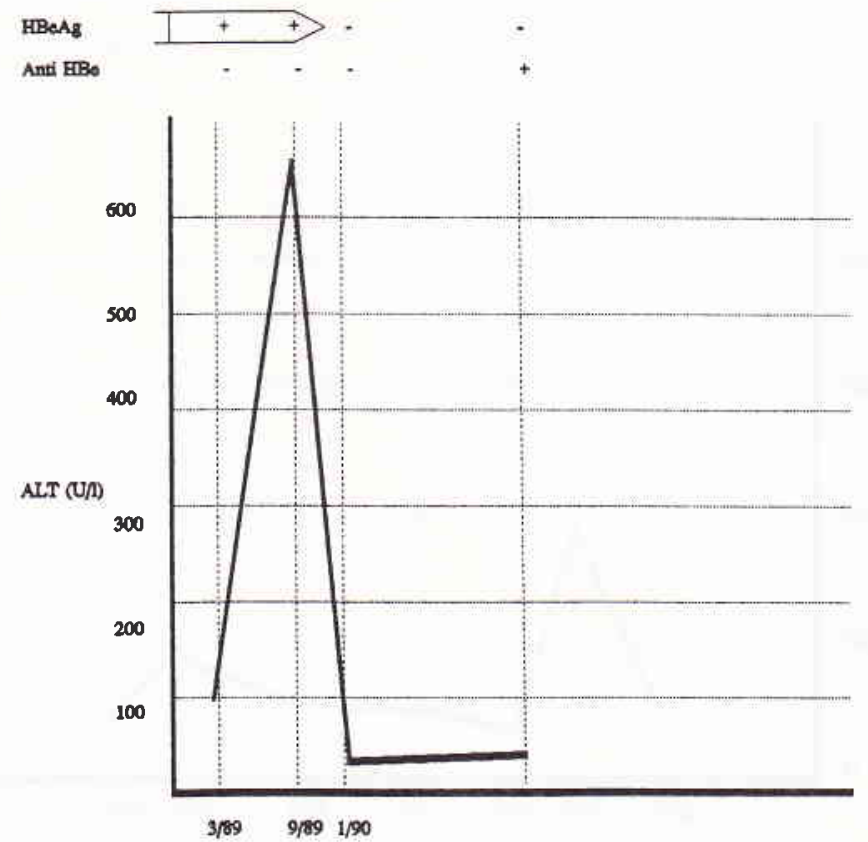

EcoR1

Hind III $+(5.5)+(5.5)$. 
CASE 4. Name : DD, Sex : Male, Age : 51 years

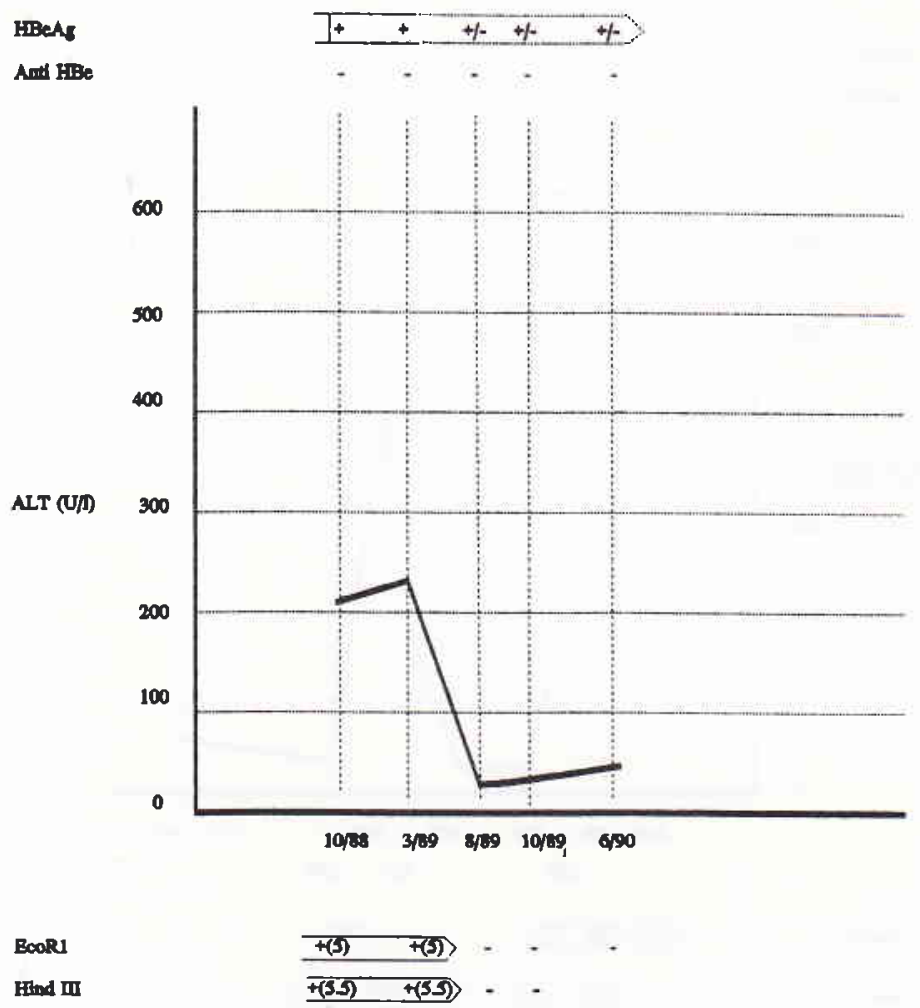

CASE 5. Name : DHD, Sex : Male, Age : 19 years

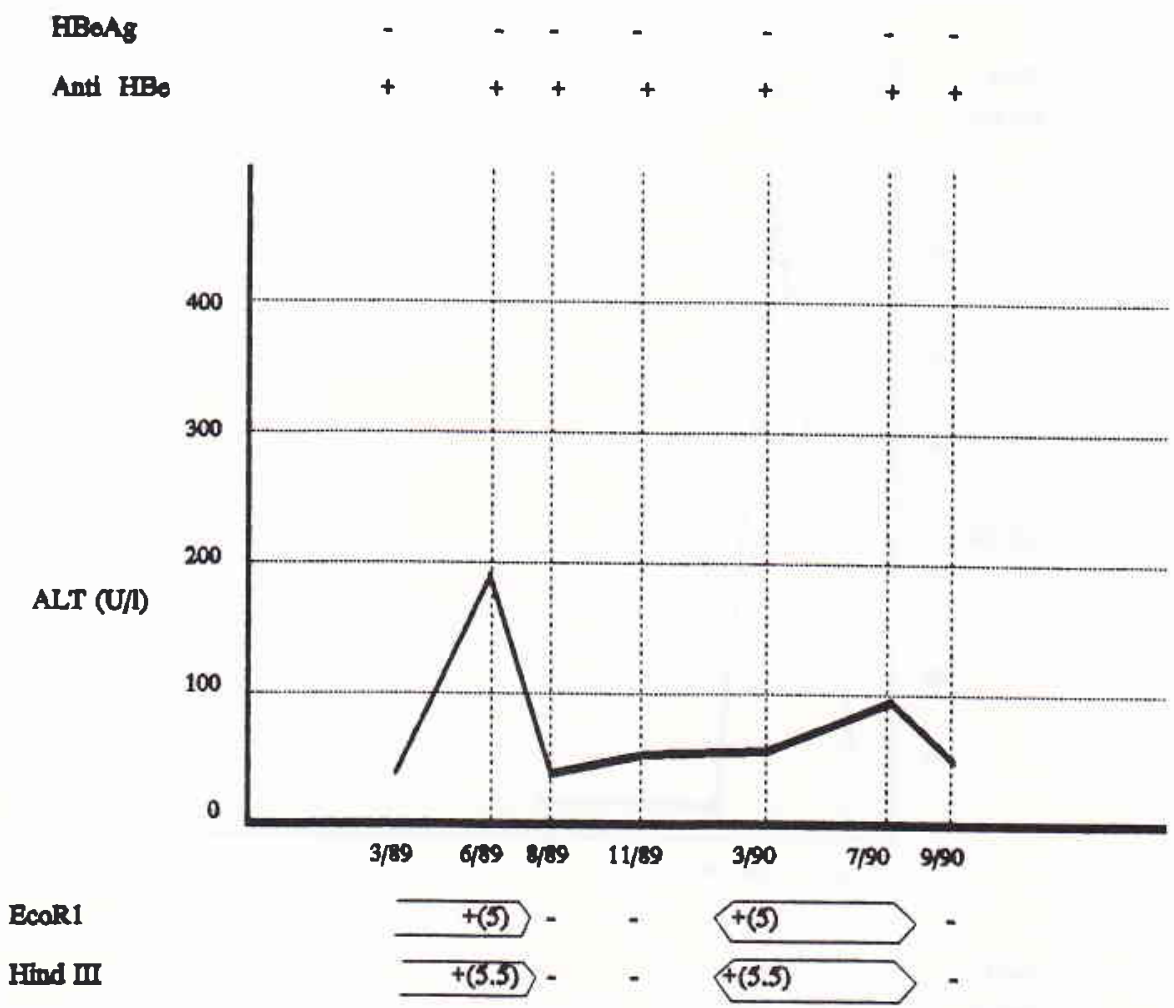


CASE 6. Name : KC, Sex : Male, Age : 50 years

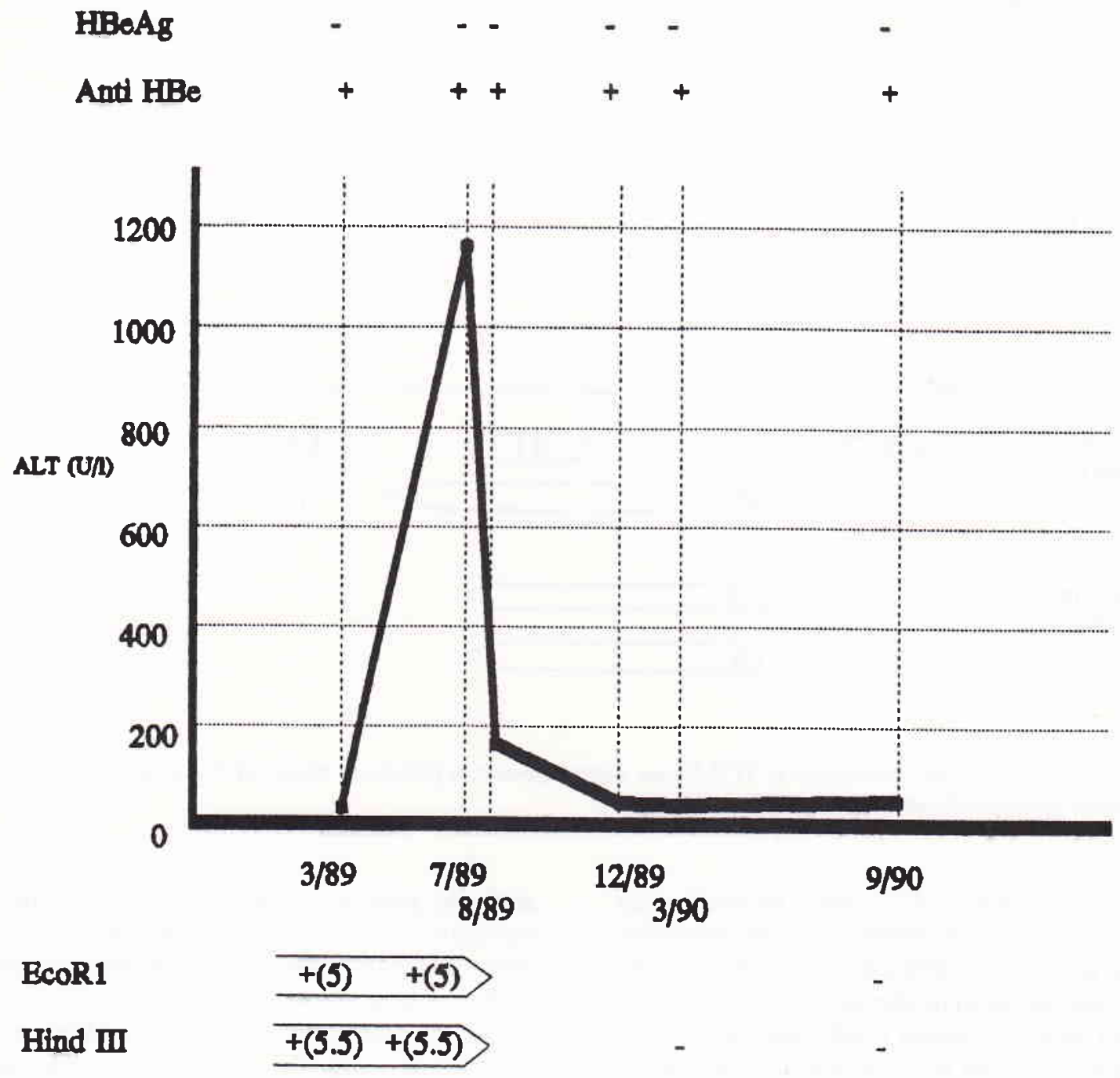

Table 1. TCR B gene rearrangement analysis during the disease course of six patients, monitored in association with serum ALT level and the presence of HBeAg in the serum.

\begin{tabular}{|c|c|c|c|c|c|c|c|c|}
\hline $\begin{array}{l}\text { ALT } \\
\text { level } \\
\text { reached }\end{array}$ & $\begin{array}{l}\text { Average } \\
\text { Period }\end{array}$ & $e^{+} / e^{-}$ & $\begin{array}{c}\text { Case } \\
1 \\
\mathrm{E} / \mathrm{H}\end{array}$ & $\begin{array}{c}\text { Case } \\
2 \\
\mathrm{E} / \mathrm{H}\end{array}$ & $\begin{array}{c}\text { Case } \\
3 \\
\mathrm{E} / \mathrm{H}\end{array}$ & $\begin{array}{c}\text { Case } \\
4 \\
\mathrm{E} / \mathrm{H}\end{array}$ & $\begin{array}{c}\text { Case } \\
5 \\
\text { E/H }\end{array}$ & $\begin{array}{c}\text { Case } \\
6 \\
\mathrm{E} / \mathrm{H}\end{array}$ \\
\hline Prior to peak & $5 \mathrm{mth}$ & + & $5 / 5.5$ & $4.5 /-$ & $-/ 5.5$ & $5 / 5.5$ & $-1-$ & $5 / 5.5$ \\
\hline At peak & $<1 \mathrm{mth}$ & + & 5.5 .5 & $5 / 5.5$ & -15.5 & $5 / 5.5$ & $5 / 5.5$ & $5 / 5.5$ \\
\hline After peak & $5 \mathrm{mth}$ & + & - & $5 /-$ & -1 & $-1-$ & $-1-$ & \\
\hline Trough & $\geq 7 \mathrm{mth}$ & - & $\mu$ & $-1-$ & $-1-$ & $-1-$ & $-1-$ & $-1-$ \\
\hline Prior to peak & $5 \mathrm{mth}$ & + & $-/ 18$ & -15.5 & -1 & & $5 / 5.5$ & \\
\hline At peak & $<1 \mathrm{mth}$ & + & $21 / 18$ & $5 / 5.5$ & & & $-1-$ & \\
\hline After peak & $5 \mathrm{mth}$ & + & $4.5 /-$ & $-1-$ & & & & \\
\hline Trough & $>7 \mathrm{mth}$ & - & $-1-$ & $-1-$ & & & & \\
\hline
\end{tabular}

Note: $\quad \mathrm{E}=\mathrm{EcoR} 1$ rearrangement band

$\mathbf{H}=$ Hind III rearrangement band $\mathrm{mth}=$ month

e $\quad$ e antigen $(\mathrm{HBeAg})$ 


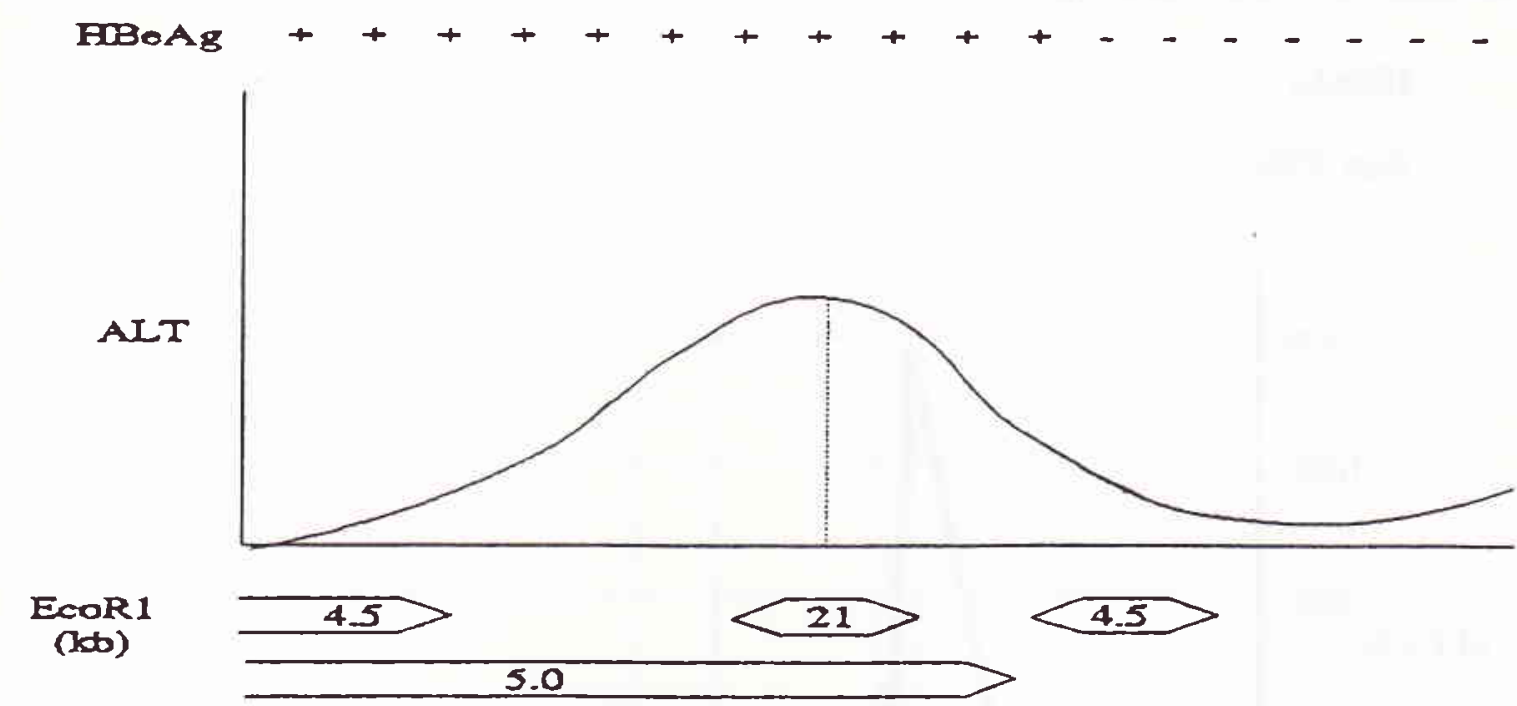

Find $\mathbf{m}$

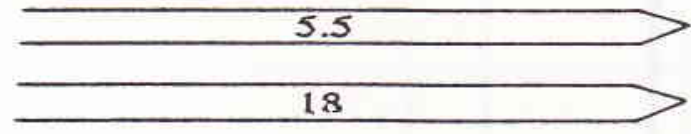

Figure 2. General pattern of the relationship of TCR $\beta$ gene rearrangement in peripheral blood, ALT level and HBeAg in the serum during the course of chronic hepatitis $B$ infection.

dent with the increase of ALT level. In some cases rearrangement bands of different size were detectable six months after soroconfersion (as in case 1). The results indicate that in some chronic HBV carriers, the expansion of peripheral blood T cell clones with $5.0 \mathrm{~kb}$ EcoR 1 and $5.5 \mathrm{~kb}$ Hind III TCR $B$ gene fragments is associated with cytotoxic clearance of virus infected hepatocytes and the loss of $\mathrm{HBeAg}$ from circulation. The clonal expansion of T cells detectable by TCR $\beta$ gene rearrangement apparently represents the progressive development of immunity to virus infection in chronic HBV carriers. The expanded $\mathrm{T}$ cell clones are most likely linked to the activity of cytotoxic $\mathrm{T}$ cells with the potential to eliminate substantial numbers of virus infected liver cells. During this elimination phase, the destruction of liver tissue is marked by the elevation of ALT level in the serum. The elimination of virus infected hepatocytes by $\mathrm{T}$ cells is the effector mechanism of virus eradication, that consequently prevents viral replication and therefore reduced the release of virions to peripheral blood. This reduction of virus replication is characterized by the disappearance of $\mathrm{HBeAg}$ and in many patients by seroconversion from being $\mathrm{HBeAg}$ positive to being anti-HBe antibody positive. When there is no sign of viral replication and the patient becomes anti-HBe positive, liver cell lysis is decreased, indicated by normal or slightly elevated ALT level. The specific $\mathrm{T}$ cells responsible for liver cell lysis would be reduced in number, as antigenic stimulation leading to clonal proliferation is over. Consequently the TCR B gene rearrangement become undetectable, since the number of such $T$ cells would be reduced to less than the threshold of detection sensitivity for TCR gene rearrangement.

Case 5 (DHD) and $6(\mathrm{KC})$ are unique in that the rearrangement of the TCR $B$ gene in peripheral blood was detectable simultaneously with rising ALT level, however the $\mathrm{HBeAg}$ was always negative during the course of the disease. As there was evidence of cytotoxic liver cell lysis (high ALT level), virus replication must have occured previously, since production of viral antigen on the liver cells drives the cytotoxic reaction. The absence of $\mathrm{HBeAg}$ during the replication phase of the disease could be associated with the failure of the virus to produce and release $e$ antigen to the circulation. This situation may occur due to mutation in the virus genes responsible for the 
secretion of $\mathrm{HBeAg}$. $\mathrm{HBeAg}$ is part of the nucleocapsid precore-core gene product; when the full precorecore gene is transcribed, the transcript will be processed and the resulting mRNA is translated into a secretory protein. Transcription of the nucleocapsid genes starts at the second initiation codon, yielding $\mathrm{HBc}$ protein which is not secreted from cells due to lack of precore encoded peptide which functions as leader directing this protein to the cell membrane, ultimately to be secreted from liver cells. ${ }^{14}$ Mutation in the precore region would lead to failure of production of leader peptide necessary for secretion of $\mathrm{HBeAg}$. Patients infected with such mutant virus would therefore never have detectable $\mathrm{HBeAg}$ in their serum, despite the presence of HBV-DNA and DNA polymerase simultaneously. This is presumably the case in patients 5 and 6.

This study describes the relationship of TCR $\beta$ gene rearrangement with the mechanism of immune mediated liver injury and virus clearance in chronic hepatitis B. It might be suggested that specific TCR $B$ gene rearrangement of $5.0 \mathrm{~kb}$ EcoR1 and / or $5.5 \mathrm{~kb}$ Hind III DNA fragments in peripheral blood are detected in chronic hepatitis B patients just prior to seroconversion. The $21 \mathrm{~kb}$ EcoR1 DNA fragment was found at the peak of ALT level, if the $5.0 \mathrm{~kb}$ EcoR1 or $5.5 \mathrm{~kb}$ Hind III DNA fragments were not detectable. This band may represent clonal expansion of $T$ cells with the activity similar to those expressing the $5.0 \mathrm{~kb}$ EcoR 1 or $5.5 \mathrm{~kb}$ Hind III DNA fragment. However, as the presence of this band is not common, its significance is unclear. As seroconversion is completed, the $5.0 \mathrm{~kb}$ EcoR 1 and / or $5.5 \mathrm{~kb}$ Hind III DNA fragments usually become undetectable and this is accompanied by dropping of ALT to normal level. This general pattern of the relationship of TCR $B$ gene rearrangement in peripheral blood with ALT level and serum $\mathrm{HBeAg}$ during the course of chronic hepatitis B infection was summarized as in table 1 and is shown diagrammatically in Figure 2. In general, the TCR $\beta$ gene rearrangement band usually of $5.0 \mathrm{~kb}$ EcoR 1 and / or $5.5 \mathrm{~kb}$ Hind III DNA fragments or sometimes 4.5 $\mathrm{kb}, 21 \mathrm{~kb}$ EcoR 1 and $18 \mathrm{~kb}$ Hind III DNA fragments are detectable during the viral clearance phase of chronic disease course. This is indicated by the flare up of ALT level and continue to resolution phase where the ALT level decreasing to normal level. The rearrangement band dissappears when ALT dropped to normal level and patient undergoes seroconversion, when the marker of virus replication is undetectable in the peripheral blood.

In conclusion, the appearance of specific TCR $\beta$ gene rearrangement in peripheral blood $\mathrm{T}$ cells of chronic hepatitis B patients apparently represents the progression of host immunity to clear the virus. The TCR $\beta$ gene rearrangement may reflect clonal expansion of $\mathrm{T}$ cells responsible for elimination of virus infected hepatocytes in the process of viral clearance, bringing the patient to seroconversion.

\section{REFERENCES}

1. Lee PI, Chang MH, Lee $\mathrm{CJ}$ et al. Changes of serum hepatitis $B$ virus DNA and aminotransferase levels during the course of chronic hepatitis B infection in children. Hepatology $1990 ; 12: 657-60$.

2. Desmet VJ. Liver lesions in hepatitis B viral infection. Yale. J Biol Med 1988; $2: 61$ - 83.

3. Paronetto F, Colucci G, Colombo M. Lymphocytes in liver diseases. vol VIII. Grune and Stratton. pp. 191-207, 1986.

4. Hoofnagle JH. Chronic hepatitis B. New Engl J Med 1990; $323: 337-9$.

5. Soeharso P. Definition of TCR gene rearrangement detection sensitivity in peripheral blood population. in $\mathrm{T}$ cell receptor gene polymorphisms and rearrangements in chronic hepatitis B, Ph.D thesis University of Queensland. pp.108 9, 1992.

6. Vento S, Hegarti JE, Alberti A et al. T lymphocyte sensitization to $\mathrm{HBcAg}$ and $\mathrm{T}$-cell mediated unresponsiveness to $\mathrm{HBsAg}$ in hepatitis B virus related chronic liver disease. Hepatol 1985; $5: 192-7$.

7. Ferrari C, Penna A, Sansoni $P$ et al. Selective sensitization of peripheral blood $\mathrm{T}$ lymphocytes to hepatitis $\mathrm{B}$ core antigen in patients with chronic active hepatitis type B. Clin Exp Immunol 1986; $67: 497$ - 506.

8. Mondelli MG, Mieli-Vergani G, Alberti A et al. Specificity of the T lymphocyte cytotoxicity to autologous hepatocytes in chronic hepatitis B virus infection : evidence that $\mathrm{T}$ cells are directed against $\mathrm{HBV}$ core antigen expressed on hepatocytes. J Immunol 1982; $129: 2773$ - 81.

9. Naumov NV, Mondelli MG, Alexander GJM. Relationship between expression of hepatitis $\mathrm{B}$ virus antigens in isolated hepatocytes and autologous lymphocyte cytotoxicity in patients with chronic hepatitis B infection. Hepatology 1984; $4: 63-8$.

10. Mondelli MG, Bortolotti F, Pontisso P et al. Definition of hepatitis B virus (HBV) specific target antigens recognized by cytotoxic $T$ cells in acute HBV infection. Clin Exp Immunol 1987; $68: 242$ - 50 .

11. Wright R. Pathogenesis of viral hepatitis. Clin Gastroenterol 1988; $4: 695-705$.

12. Thomas HC. Pathogenesis of chronic hepatitis B. J Gastroenterol Hepatol Suppl. 1991; $1: 4$ - 6.

13. Moebius U, Manns $M$, Hess $G$ et al. $T$ cell receptor gene rearrangements of $T$ lymphocytes infiltrating the liver in in chronic active hepatitis B and primary biliary cirrhosis $(\mathrm{PBC})$ : Oligoclonality of PBC-derived T-cell clones. Eur $\mathrm{J}$ Immunol 1990; $20: 889$ - 6.

14. Carman WF, Jacyna MR, Hadziyannis $S$ et al. Mutation preventing formation of hepatitis $\mathrm{B} e$ antigen in patients with chronic hepatitis B infection. Lancet 1989; 2 : 588-90. 